
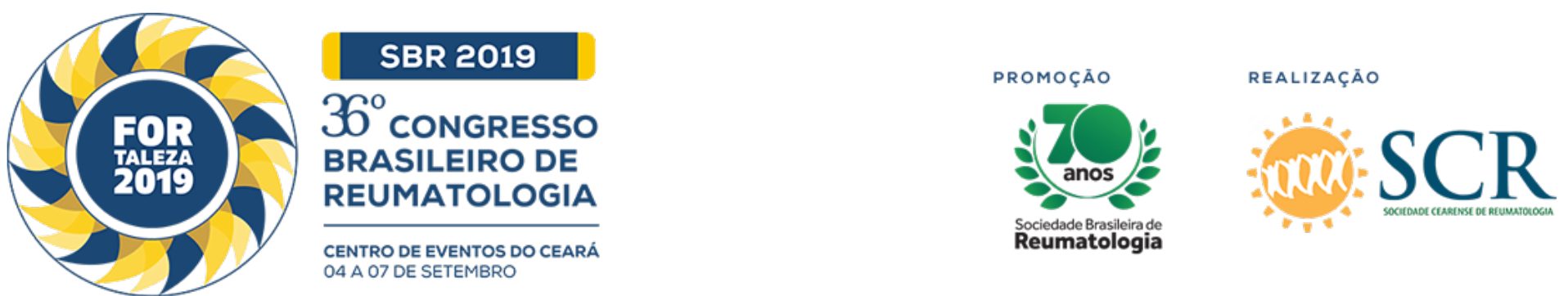

\title{
INTESTINAL HISTOLOGICAL FINDINGS IN SPONDYLOARTHRITIS PATIENTS AND IT'S ASSOCIATION WITH DISEASE ACTIVITY
}

Juliana Simioni (Hospital Universitário Evangélico Mackenzie, Curitiba, PR, Brasil), Ana Paula Beckhauser Campos (Hospital Universitário Evangélico Mackenzie, Curitiba, PR, Brasil), Betania Longo (Hospital Universitário Evangélico Mackenzie, Curitiba, PR, Brasil), Lorete Maria Silva Kotze (Pontífice Universidade Católica do Paraná, Curitiba, PR, Brasil), lara José Taborda Messias-Reason (Universidade Federal do Paraná, Curitiba, PR, Brasil), Sergio Ossamu loshii (Pontífice Universidade Católica do Paraná, Curitiba, PR, Brasil), Renato Mitsunori Nisihara (Universidade Federal do Paraná, Curitiba, PR, Brasil), Thelma Larocca Skare (Hospital Universitário Evangélico Mackenzie, Curitiba, PR, Brasil)

\section{BACKGROUND}

Background: Although inflammatory bowel disease has been detected in around 7\% of SpA, almost $65 \%$ of SpA patients will have asymptomatic bowel inflammation if assessed by capsule endoscopy or ileocolonoscopy. Nowadays, the link between intestinal inflammation and SpA originated the gut-joint axis hypothesis that states that monocytes and T cells found in the joint have origin in the gut. Aim: To study the association of histological findings of intestinal wall of SpA patients with disease activity index.

\section{MATERIALS AND METHODS}

Methods: Intestinal biopsies taken from terminal ileum, right, transverse and left colon and rectum of 27 SpA patients submitted to ileocolonoscopy were stained by hematoxylin-eosin and studied for the presence and intensity of lymphoplasmacytic infiltrates, lymphoid hyperplasia, eosinophil infiltrates and erosion. Lymphoplasmacytic infiltrate was quantified according to ERBEN et al. parameters. Pain and disease activity were measured by a visual analogic scale (VAS) of pain, ASDAS (Ankylosing Spondylitis Activity Score)-ESR (Erythrocyte sedimentation rate), ASDAS-CRP (C reactive protein) and BASDAI (Bath Ankylosing Spondylitis Disease activity index).

\section{RESULTS}

Results: The most common finding was eosinophilic infiltrates. The result of the sum of scores of each segment of intestinal finding showed the following correlations: lymphoplasmacytic infiltrate with ASDASESR ( $\mathrm{rho}=0.49 ; 95 \% \mathrm{Cl}=0.03-0.78 ; \mathrm{p}=0.03$ ) and ASDAS-CRP ( $\mathrm{rho}=0.54 ; 95 \% \mathrm{Cl}=0.10-0.80 ; \mathrm{p}=0.01$ ); eosinophilic infiltrate with ASDAS-CRP ( $\mathrm{rho}=0.48 ; 95 \% \mathrm{Cl}=0.02-0.77 ; \mathrm{p}=0.04)$ and lymphoid hyperplasia with VAS of pain ( rho $=-0.83 ; 95 \% \mathrm{Cl}=-0.95$ to $-0.44 ; \mathrm{p}=0.007$ ).

\section{CONCLUSION}

Conclusion: There is a high prevalence of histological findings in the intestinal biopsies of SpA patients; the most common is eosinophilic infiltrates. The intensity of eosinophil and lymphoplasmacytic infiltrates correlates with the rheumatic disease activity indexes. 